\title{
Response of Strawberry Plants to Bio Fertilization with Methylotrophic Bacteria
} M.S.EL-Badawy ${ }^{I}$, F.A.Abo-Sedera ${ }^{I}$, L.A.Badr ${ }^{I}$,M. M.ELNagar ${ }^{I}$ and A.Abou EL-Yazied ${ }^{2}$

\author{
${ }^{1}$ Hort.Dept.,Faculty of Agriculture, Benha,Univ, Benha, Egypt \\ ${ }^{2}$ Hort.Dept, Faculty of Agriculture, Ain Shams,Univ, Egypt \\ E-Mail: Msaedmsaed140@gmail.com
}

\begin{abstract}
Two field experiments were carried out during the two successive seasons of 2014/2015 and 2015/2016 in private sector farm at El-Dair village, Kalubia governorate in sandy soil to investigate the response of two strawberry cultivars namely Fortuna and Sweet Charlie, transplants root dipping or without dipping in methylotrophic bacteria and sprayed up to six times with methylotrophic bacteria $\left(10 \mathrm{~cm}^{3} / 1\right)$ on vegetative growth, chemical composition and productivity of some strawberry cultivars. Obtained results showed that there were significant differences among the studied strawberry cultivars in all measured vegetative growth traits, fruit yield and its components as well as fruit quality. In this respect, cv. Fortuna reflected the highest values of vegetative growth, chemical composition of plant foliage, fruit yield and its components and physical and chemical fruit quality. Also foliar spraying plants six times with methylotrophic bacteria at $10 \mathrm{~cm}^{3} / 1$ starting after 20 days from transplanting and every 15 days by intervals during the growth season was superior in total and marketable fruit yield. Different tested bio-fertilization (methylotrophic bacteria) enhanced the vegetative growth, chemical constituents of plant foliage, total produced fruit yield and its components as well as fruit quality. In addition, using methylotrophic bacteria at $10 \mathrm{~cm}^{3} / 1$ reflected the highest values in all studied growth and yield traits of tested cultivars.
\end{abstract}

Key words: Strawberry, Cvs. fortuna and sweet charlie, Methylotrophic bacteria, Vegetative growth, Fruit yield, Fruit quality.

\section{Introduction}

Strawberry (Fragaria X anannasa Duch.) is one of the most important vegetable crops grown in Egypt for fresh consumption, processing and exportation. It's the unique vegetable crop belongs to family Rosaceae. The total area devoted to grow strawberry in Egypt was increased and reached about 21573.9 fed. from which 16459.21fed. for fresh production with an average yield of $20 \mathrm{t} / \mathrm{fed}$ and 5113.12 fed. for frigo production with an average yield of $13.14 \mathrm{t} / \mathrm{fed}$. Moreover, the total exportable fruit yield was 22 thousand ton according to the statistics of Egyptian Ministry of Agriculture and Land Reclamation in 2015-2016 season. The growth, production and quality of strawberry plants are depending on the different agricultural treatments done during the growing season.

Nowadays, many farmers used fertilization and spraying with bio fertilizers on plant foliage to improve growth, productivity and yield quality of produced fruits. Also, within the last few years several materials such as methylotrophic bacteria were tested on some vegetable and field crops to improve growth and productivity. Many investigators working on foliar spray of plants with methylotrophic bacteria [ $11,5,3]$ found that methylotrophic bacteria enhanced plants growth, productivity and yield quality of produced fruits. Fruit characteristics usually show great variability among the various strawberry cultivars. Fruit size is one of the most important aspects in evaluating strawberry cultivars. Investigators working on foliar spray on strawberry plants [22, 13,28$]$ found that methylotrophic bacteria enhanced growth, productivity and quality of produced fruits. Nowadays many farmers used fertilization and spraying with bio fertilizers on plant foliage to improve growth, productivity and quality of produced fruits.

Therefore, the present study aims to investigate the response of strawberry cultivars to bio fertilization (spray with methylotrophic bacteria) on vegetative growth, productivity and quality of produced strawberry fruits.

\section{Matarials \& methods}

Two field experiments were carried out during the two successive seasons of 2014/2015 and $2015 / 2016$ in a private sector farm at El-Dair village, Kalubia governorate. This experiment was carried out to investigate the response of two strawberry cultivars namely Fortuna and Sweet Charlie to bio fertilization and spraying with (methylotrophic bacteria) on vegetative growth, chemical composition, fruit yield and its components as well as fruit quality of tested cultivars. The tested spray substance was added individually at the recommended dose (methylotrophic bacteria $10 \mathrm{~cm} 3 / 1$ ), respectively. The texture of the experimental field was sandy soil. Random soil samples were taken before planting for physical and chemical analyses Table (a).The fresh transplants of the used cultivars were obtained from Modern Agriculture Company Pico Egypt.

The area of the experimental plot was $10.20 \mathrm{~m} 2$ included three beds each six meters in length and 1.70 meters in width. Each bed included four rows at $25 \mathrm{~cm}$ apart. 
Transplanting was done at $25 \mathrm{~cm}$ apart between transplants in the same row. planting was done on 1 st of October in 2014/2015 and 2015/2016. Sprinkler irrigation was used in the first month after transplanting, after that the beds were covered with 40 micron white plastic mulch.
After that the drip irrigation was used after mulching until the end of the growing season. Foliar application treatments were started after 20 days from transplanting and every 15 days by intervals on the plants were sprayed, 2, 4, 6 times through out the growing season.

Table (a) Physical and chemical analyses of the used soil

\begin{tabular}{llllll}
\hline Physical analysis & \multicolumn{5}{l}{ Chemical analysis } \\
\cline { 3 - 6 } & & \multicolumn{2}{l}{ Cations } & \multicolumn{2}{l}{ Anions meq/l } \\
\hline Coarse sand & $18 \%$ & $\mathrm{Ca}^{++}$ & 7.6 & $\mathrm{CO}^{--}$ & Zero \\
Fine sand & $36.6 \%$ & $\mathrm{Mg}^{++}$ & 3.3 & $\mathrm{HCO}^{-}$ & 3.7 \\
Silt & $27.1 \%$ & $\mathrm{Na}^{+}$ & 4.20 & $\mathrm{Cl}^{-}$ & 5.4 \\
Clay & $18.3 \%$ & $\mathrm{~K}^{+}$ & 3.9 & $\mathrm{SO}^{-}$ & 7.7 \\
Texture class sandy & & & & & \\
Soil pH & 7.3 & & & & \\
E.C, dS/m & 1.65 & & & & \\
Organic matter & $2.4 \%$ & & & & \\
\hline
\end{tabular}

Table (b) Monthly air temperature and relative humidity in Kalubia region during the two seasons of the experimental work

\begin{tabular}{lllllllll}
\hline \multirow{2}{*}{ Months } & \multicolumn{2}{l}{$\mathbf{2 0 1 4 / 2 0 1 5}$} & \multicolumn{3}{l}{$\mathbf{2 0 1 5 / 2 0 1 6}$} \\
\cline { 2 - 10 } & \multicolumn{2}{l}{ Tmperature $\left({ }^{\circ} \mathbf{C}\right)$} & \multicolumn{2}{l}{ R H (\%) } & \multicolumn{3}{c}{ Tmperature $\left({ }^{\circ} \mathbf{C}\right)$} & \multicolumn{2}{c}{ R H $(\%)$} \\
\cline { 2 - 10 } & Max & Min & Max & Min & Max & Min & Max & Min \\
\hline September & 40.2 & 23.9 & 90.0 & 12.0 & 40.6 & 28.7 & 100 & 21.0 \\
October & 34.9 & 15.6 & 91.2 & 15.7 & 36.9 & 13.9 & 89.6 & 16.2 \\
November & 30.5 & 10.7 & 95.3 & 18.6 & 30.2 & 12.8 & 100 & 29.2 \\
December & 30.2 & 6.2 & 100.0 & 23.5 & 23.5 & 7.2 & 100 & 28.1 \\
January & 28.7 & 3.7 & 96.4 & 12.6 & 22.9 & 3.8 & 100 & 24.5 \\
February & 29.9 & 5.5 & 100 & 10.5 & 31.2 & 5.9 & 100 & 14.7 \\
March & 35.7 & 10.2 & 97.9 & 11.8 & 33.3 & 11.3 & 100 & 9.7 \\
April & 38.0 & 10.8 & 94.4 & 6.8 & 40.7 & 13.3 & 100 & 7.0 \\
May & 40.0 & 16.5 & 87.8 & 7.6 & 40.3 & 16.6 & 86.4 & 8.8 \\
\hline
\end{tabular}

Central Laboratory of Agriculture Climate,Ministry of Agriculture,Egypt

Table (c) Comparison between the tested two strawberry cultivars Sweet Charlie and Fortuna

\begin{tabular}{lcc}
\hline Characteristics & Sweet Charlie & Fortuna \\
\hline Vegetative growth & medium & medium \\
Early fruits & very early & very early \\
Exportable yield & high & Very high \\
Fruit firmness & low & low \\
Storability & low & low \\
Fruit sugars and vitamin C & high & high \\
Fruit size at the end of the season & small & Big \\
Botrytis infection & high & high \\
\hline
\end{tabular}

\subsection{Methylotrophic bacteria}

2.1.1 Preparation of pink pigmented facultative methylotrophic (PPFM) bacteria Quantification of Indole Acetic Acid (IAA)

Isolates of PPFM were grown in minimal broth medium (DSM 125) in the presence of the auxin precursor (tryptophan, $1 \mathrm{mM} / \mathrm{L}$ ). The inoculated flasks were incubated on the rotary shaker (150 $\mathrm{rpm})$ at $25^{\circ} \mathrm{C}$ for 4 days in dark. The IAA was quantified, using the colorimetric technique by Salkoweski reagent as described by [ 16 ]. After removing the cells by centrifugation at $10000 \mathrm{x} \mathrm{g}$ for $30 \mathrm{~min}$, the liquid culture was mixed $1: 1(\mathrm{v} / \mathrm{v})$ with salkoweski reagent $\left(12 \mathrm{~g} / \mathrm{L} \mathrm{Fecl} 3,7.9 \mathrm{MH}_{2} \mathrm{SO}_{4}\right)$ and incubated for $30 \mathrm{~min}$ in dark. Thereafter, the optical density was measured using a spectrophotometer at wavelength $530 \mathrm{~nm}$. Amounts 
of IAA were calculated according to the standard curve of IAA.

\subsubsection{Cytokinin Determination :}

The isolates of PPFM were grown in $\mathrm{K}$ medium with $0.5 \%$ methanol [ 12 ]. Cells were harvested by centrifugation at $10000 \mathrm{x} \mathrm{g}$ for $30 \mathrm{~min}$ and the supernatant was used for analysis of cytokinins. The technique of [ 15 ] was adopted. Cucumber (Cucumus sativus L.) and Beta Alfa seeds were germinated in Petri dishes in dark at $28^{\circ} \mathrm{C}$. After 6 days, the cotyledons were excised in dim green light and placed in $5 \mathrm{~cm}$ Petri dishs (10 cotyledons in each) containing $6 \mathrm{ml}$ of the supernatant of each tested culture. The dishes were returned back to the dark at $28^{\circ} \mathrm{C}$ for $14 \mathrm{~h}$ then moved into fluorescent light with an intensity of $220 \mathrm{ft} . c$. After $3 \mathrm{~h}$, the chlorophyll from 10 cotyledons was extracted with cold acetone, brought up to a volume of $10 \mathrm{ml}$ and centrifuged determined by measuring their absorbance at $665 \mathrm{~nm}$. Amounts of cytokinins were calculated based on standard curve of cytokinins.

NPK fertilizers were added at the recommended dose $\left(200 \mathrm{~kg} \mathrm{~N}+80 \mathrm{~kg} \mathrm{P}_{2} \mathrm{O}_{5}+240 \mathrm{~kg} \mathrm{~K}_{2} \mathrm{O} / \mathrm{fed}\right)$ in the form of ammonium sulphate $\left[\left(\mathrm{NH}_{4}\right)_{2} \mathrm{SO}_{4}, 20.5 \%\right.$ $\mathrm{N}]$, phosphoric acid $60 \% \quad \mathrm{P}_{2} \mathrm{O}_{5}$ and potassium sulphate $\left(48 \% \mathrm{~K}_{2} \mathrm{O}\right)$ were used as a source of nitrogen, phosphorus and potassium, respectively. The amounts of mineral fertilizers were divided into equal portions and were added through the irrigation water (fertigation) two times per week starting 21 days after transplanting and ended 15 days before the end of harvesting season. All other agricultural treatments required for fresh plantation of strawberry were done as commonly followed in the district.

This experiment included 16 treatments resulted from the combination of two strawberry cultivars, tow pre- transplanting treatments for transplants and four spray treatments as follows :-

Tested strawberry cultivars :- Fortuna and Sweet Charlie.

Pre- transplanting treatments :- Transplants roots were dipped in solution of methylotrophic bacteria at $10 \mathrm{~cm}^{3} / 1$ for 10 minutes before transplanting. Transplants roots were dipped in distilled water as control for 10 minutes before transplanting.

Spray treatments :- The foliar spray treatments using methylotrophic bacteria at rate $10 \mathrm{~cm}^{3} / 1$ were started 20 days after transplanting as follows:-

As Control, (plants were sprayed by distilled water only). Spraying two, four or six times during the growing season (plants were sprayed after 20 days from transplanting and two weeks later). A split split design with four replicates was adopted where the main plots were determined for cultivars and sub plots for pre-transplanting dipping treatments as well as sup sub plots for number of foliar spray treatments.
2.2 Data recorded

2.2.1 Vegetative growth characteristics

Five plants were taken from each experimental plot as a representative sample on January after 110 days from transplanting and the following data were recorded.

Plant height it was measured from the highest point of the plant up to the crown surface.

Fresh weight per plant. Dry weight per plant, five plants were dried in an oven at $70^{\circ} \mathrm{C}$ for $72^{\mathrm{h}}$ until constant weight. The dried plants were weighted and dry weight per plant was calculated.

Number of crowns/plant. Number of leaves/plant. Leaf area was determined on weight basis where ten discs each of one $\mathrm{cm}^{2}$ area were taken, and dried in an oven at $70{ }^{\circ} \mathrm{C}$ until constant weight. The rest of the leaves were similarly dried. Based on the known dry weight of a known surface area of leaves, i.e., leaf discs, and the total weight of leaves, leaf surface area was determined. Crown diameter was measured by using vernier caliber.

\subsubsection{Chemical composition of plant foliage}

Photosynthetic pigments: chlorophyll reading of the fifth mature leaf (full expanded leaf) from the top was measured at 90 days from transplanting using minolta chlorophyll meter SPAD-502 according to [ 32 ].

Total nitrogen, phosphorus and potassium were determined in the digested dry matter of plant foliage according to the methods described by 19 , 31,8 ], respectively. Total protein: protein content was calculated by using the conversion factor $(\mathrm{N} \times$ 6.25) as described by [ 25 ].

Total carbohydrates was determined colorimetrically according to method described by [18 ].

\subsubsection{Fruit yield and its components}

Early fruit yield /fed was determined as weight of all harvested fruits at the ripe stage during November, December and January. Total fruit yield /fed was calculated using plot yield and plot area. Fruit yield / plant was calculated from fruit yield/plot and number of plants/plot. Marketable yield /fed was calculates after discarding the infected fruits. Un-marketable yield /fed was calculated as weight of infected fruit during the harvesting season.

\subsubsection{Fruit quality}

\subsubsection{Physical quality:}

A random sample of 10 fruits at marketable stage from each experimental plot was taken to determine the following properties: length and diameter were 
measured for fruit sample (10 fruits) using vernier caliber.

\section{Average fruit weight.}

Fruit firmness was determined by using Chatillon Penetrometer (N.4., USA) GauGe -R with a needle $3 \mathrm{~mm}$ in diameter. [ 26 ].

\subsubsection{Chemical quality}

Total soluble solids\% (T.S.S.\%): A random sample of 10 fruits from each experimental plot at full ripe stage was taken to determine the percentage of soluble solids content by using hand refractometer.

Total titratable acidity (T.T.A): A random sample of $100 \mathrm{~g}$ of fruit at full ripe stage for each experimental plot was taken to determine T.T.A. of juice by titration with $0.1 \mathrm{~N} \mathrm{NaOH}$ (Sodium hydroxide) solution using phenol phthalin indicator, according to the method described in [ 1 ].

Ascorbic acid "Vitamin C" was determined in the same sample taken for acidity measurement using the indicator of 2,6 dichlorophenol indophenol for titration as the method mentioned in [ 1 ].

Total sugars: Were determined in dry samples of ripe fruits for each experimental plot colormetrically by the method described by [30 , 23].

Anthocyanin pigmant: was determined spectrophotometerically as described by [1].

Statistical analysis :- Data were subjected to statistical analysis by the method of Duncan's multiple range test as reported by [17]. All statistical analysis was performed with SAS computer software.

\section{Results and discussion \\ 3.1 Vegetative growth characteristics \\ 3.1.1 Effect of cultivars}

Data in Table (1) reveal that, cv. Fortuna produced mostly the highest significant values of all vegetative growth measurements under study during the two seasons of growth. Meanwhile, cv. Sweet Charlie gave the highest values of number of leaves and crown per plant during the first season only. Such differences in vegetative growth characteristics among the studied cultivars may be attributed to the differences in genetical structure between such cultivars. Obtained results are in agreement with those reported by [4, 22, 13 ] on strawberry who indicated that there were significant differences in most studied growth measurements among the tested cultivars.
3.1.2 Effect of transplant root dipping in methylotrophic bacteria

Data in Table (1) indicate that dipping the transplant roots in methylotrophic bacteria at concentration of $10 \mathrm{~cm}^{3} / 1$ significantly increased most of studied vegetative growth characteristics compared with non roots dipping treatment (control) during the two seasons of growth, except dry weight per plant, number of leaves and crowns per plant during both seasons and leaf area during the first season and fresh weight per plant during the second one which were not significantlyaffected. In this concept, dipping the plant roots in methylotrophic bacteria exhibited the highest values in all vegetative growth characteristics traits followed by non dipping treatment in descending order. Positive effects of Methylotrophic bacteria effect on plant growth may be due to various mechanisms that include solubization and uptake of nutrints and stimulate phytohormone synthesis [7].

\subsubsection{Effect of number of foliar sprayes with methylotrophic bacteria}

As for the effect of number of foliar spray with methylotrophic bacteria at $10 \mathrm{~cm}^{3} / 1$ concentration which starting after 20 days from transplanting and every 15 days by intervals on vegetative growth characteristics of strawberry plant, data in Table (1) reveal that there were significantly differences among the used number of foliar spraying treatments in all measured vegetative growth characteristics of plant compared with the control treatment during the two seasons of growth, except dry weight per plant which was not significantly affected during the two seasons of growth. In this regard, foliar spraying of plants with methylotrophic bacteria at $10 \mathrm{~cm}^{3} / 1$ concentration six times starting after 20 days from transplanting and every 15 days by intervals through the growing season show the highest values for all vegetative growth aspects expressed as plant height, fresh and dry weight of plant, leaves and crowns number per plant, average leaf area and crown diameter per plant during both seasons of study followed by four and two times of foliar spraying in adescending order. These results were true during the two seasons of growth. Such enhancing effect of methylotrophic bacteria may be due to the improvement of plant growth through the production of enzyme urease or phytohormones like indole-3-acetic acid (IAA) and cytokinins [24, 20 , ]. Obtained results are similar to those reported by $[14,5,3]$ used yeast extract and methylotrophic bacteria on deferent plant crops.

\subsubsection{Effect of the interaction}

Concerning the effect of interaction between cultivars and transplant roots dipping in methylotrophic bacteria at $10 \mathrm{~cm}^{3} / 1$ concentration, 
data in Table (1) show that there were significantly differences between interaction treatments in case of plant height and leaf area per plant during the two seasons of growth and fresh weight per plant and crown diameter during the first season only. Meanwhile the values of dry weight per plant as well as number of leaves and crown per plant did not reach the level of significance during the two seasons of study. In this respect, the highest values in all vegetative growth characteristic traits were recorded as a result of the interaction between $\mathrm{cv}$. Fortuna combined with dipping seedling roots before transplanting in methylotrophic bacteria at $10 \mathrm{~cm}^{3} / 1$ concentration, except number of leaves per plant during the first season which exhibit the highest values as a result of the interaction treatment between cv. Sweet Charlie and dipping seedling roots before transplanting in methylotrophic bacteria.

As for the effect of the interaction between transplant roots dipping and number of foliar spray with methylotrophic bacteria at $10 \mathrm{~cm}^{3} / 1$ concentration, data in Table (1) reveal that there were significant differences in most vegetative growth characteristics traits as a result of the interaction treatments compared with the control. In addition, the highest values were noticed in case of using the interaction treatment between dipping transplant roots in methylotrophic bacteria and foliar spraying plants six times during the growth season using methylotrophic bacteria starting after 20 days from transplanting and every 15 days by intervals followed by the interaction treatments between without dipping and foliar spray followed by six times dipping of transplant roots combined with four times foliar sprays without any significant differences between them for plant height, fresh and dry weight of plant, leaves and crown number per plant and crown diameter per plant and leaf area per plant. This results were true during the two seasons of growth.

With regard to the effect of the interaction treatments between cultivars and number of foliar sprays with methylotrophic bacteria at $10 \mathrm{~cm}^{3} / 1$ concentration, the data in Table (1) show clearly that vegetative growth characteristics, i.e. plant height, fresh and dry weight of plant, leaves and crowns number per plant, average leaf area and crown diameter per plant significantly affected by the interaction treatments. In this connection, using cv. Fortuna and foliar spraying plants six times during the growing season starting after 20 days from transplanting and every 15 days by intervals by using methylotrophic bacteria at $10 \mathrm{~cm}^{3} / 1$ concentration recorded the highest values in all traits of vegetative growth characteristics under study compared with the control and other tested spraying treatments during the growth seasons, followed by using the interaction treatments between cv. Fortuna and four times foliar sprays.
On the other hand, the lowest values in all morphological parameters were obtained from using the control treatment followed by the interaction treatment between cv. Sweet Charlie and foliar spray the plants two times during the two growth seasons.

Regarding the effect of the interaction treatments between each of cultivars, transplant roots dipping and number of foliar sprays with methylotrophic bacteria at $10 \mathrm{~cm}^{3} / 1$ concentration on vegetative growth parameters, data in Table (1) indicate that all morphological traits were significantly increased as a result of all interaction treatments compared with the control during the two seasons of growth. Meanwhile, number of crowns per plant during the two growth seasons and dry weight per plant during the second season only did not reach the level of significance. Whereas, using cv. Fortuna and dipping seedling roots before transplanting in methylotrophic bacteria as well as foliar spraying the plants six times with the same bacteria during the growth season starting after 20 days from transplanting and every 15 days by intervals recorded the highest values for plant height, fresh and dry weight of plant, leaves and crowns number per plant, average leaf area and crown diameter per plant followed by cv. Fortuna with dipping seedling roots combined with four times foliar sprays the plants as well as the interaction treatment between cv. Fortuna and without dipping seedling roots with six times foliar sprays during the growth season. This result was true during the two seasons of growth.

\subsection{Chemical composition of plant foliage 3.2.1 Effect of cultivars}

Concerning the effect of tested cultivars on chemical constituents of plant foliage, data in Table (2) indicate that chemical composition of plant foliage expressed as chlorophyll reading, total nitrogen, phosphorus, potassium, total crude protein and total carbohydrates percentages of plant foliage were significantly different among the tested cultivars except $\mathrm{P} \%$ in the first season and chlorophyll reading in both seasons of study, which did not reach the $5 \%$ level of significance. In this respect, cv. Fortuna recorded the highest values in all assayed chemical constituents compared with cv. Sweet Charlie during both growth seasons. Meanwhile, cv. Sweet Charlie recorded the highest values of potassium only during the two seasons. In this connection, such differences in chemical composition of plant foliage may be due to the difference in genetic structure of tested cultivars which may affect mineral absorbation by plant roots and carbohydrates assimulation in photosynthetic process in plant foliage. Obtained results are similar to those reported by [22, 13] who found that total nitrogen and phosphorus were differed among the tested cultivars. 
3.2.2 Effect of transplant roots dipping in methylotrophic bacteria

Concerning the effect of transplant roots dipping in methylotrophic bacteria at $10 \mathrm{~cm}^{3} / 1$ concentration for 10 minuts before transplanting, data in Table (2) reveal that there were significantly differences among dipping or without dipping roots in all measured chemical constituents of plant foliage, i.e., chlorophyll reading, $\mathrm{N} \%, \mathrm{P} \%, \mathrm{~K} \%$, total crude protein and total carbohydrates $\%$ during both seasons of study except chlorophyll reading in the first season and $\mathrm{N} \%$ and total crude protein $\%$ in the second one which did not reach the level of significance. In this regard, dipping strawberry seedling roots before transplanting in the soil in methylotrophic bacteria at $10 \mathrm{~cm}^{3} / 1$ concentration for 10 minuts exhibited the highest values in all studied chemical constituents of plant foliage compared with the control treatment (without dipping). These results were true during both seasons of growth. Inoculation with methylotrophic bacteria was found to increase the photosynthetic activity by enhancing chlorophyll concentration [9]. These effects might be mediated by producing plant growth regulators like ziatin and related cytokinins and auxins [24].

\subsubsection{Effect of number of foliar sprays with methylotrophic bacteria}

With regard to the effect of number of foliar sprays with methylotrophic bacteria at $10 \mathrm{~cm}^{3} / 1$ concentration which starting after 20 days from transplanting date and every 15 days by intervals on chemical constituents of strawberry plant foliage, the same data in Table (2) reveal that there were significant differences among the used number of foliar spraying treatments in all measured chemical constituents of plant foliage compared with the control treatment during both seasons of growth. In this regard, spraying plants with methylotrophic bacteria at $10 \mathrm{~cm}^{3} / 1$ concentration six times starting after 20 days from planting dates and every 15 days by intervals showed the highest values for all chemical constituents of plant foliage expressed as chlorophyll reading, $\mathrm{N} \%, \mathrm{P} \%, \mathrm{~K} \%$, total crude protein $\%$ and total carbohydrates followed by four and two times of foliar sprays. These results were true during both seasons of growth. Such positive effects of Methylotrophic bacteria plant growth through various mechanisms that include solubization and uptake of nutrints, in addition to phytohormone synthesis [7].

In this regard, $[2,6,3]$ used yeast extract and methylotrophic bacteria as growth enhancing stimulants foliar spray and found that treating of the tested vegetables crops increased the different assayed chemical constituents of plant foliage.

\subsubsection{Effect of the interaction}

As for the effect of the interaction between cultivars and dipping in methylotrophic bacteria at $10 \mathrm{~cm}^{3} / 1$ concentration, data in Table (2) indicate that there were significant differences in all chemical constituents of plant foliage due to the interaction between the two studied factors except chlorophyll reading in both seasons and phosphorus\% only in the first one which did not reach the 5\% level of significance. In this respect, Fortuna cultivar combined with dipping plant roots in methylotrophic bacteria at $10 \mathrm{~cm}^{3} / 1$ concentration reflected the highest values for $\mathrm{N} \%, \mathrm{P} \%$, total crude protein and total carbohydrates. Meanwhile, Sweet Charlie cultivar combined with dipping plant roots reflected the highest values for chlorophyll reading and $\mathrm{K} \%$ during the two seasons of growth.

With regard to the interaction between transplant roots dipping and number of foliar sprays with methylotrophic bacteria at $10 \mathrm{~cm}^{3} / 1$ concentration starting after 20 days from transplanting and every 15 days by intervals, data in Table (2) show that there were significant differences in all chemical constituents of plant foliage due to the interaction between the two studied factors. Obtained results are true during the both seasons of study. In this respect, the highest values were recorded as a results of dipping seedling of strawberry before transplanting in methylotrophic bacteria combined with foliar spray plants six times with methylotrophic bacteria at $10 \mathrm{~cm}^{3} / 1$ concentration for all chemical constituents of plant foliage followed by the interaction between dipping transplant, combined with four times of foliar spray and the interaction between without dipping with six times of foliar spray without any significant differences between them for all chemical constituents of plant foliage.

\subsection{Fruit yield and its components \\ 3.3.1 Effect of cultivars}

Data in Table (3) show clearly that there were significant differences among the tested cultivars in total produced fruit yield and its components expressed as total fruit yield plant, early yield, marketable and unmarketable fruit yield as well as total fruit yield feddan during both seasons of study except early yield per feddan in the first season which did not reach the $5 \%$ level of significance. In this connection, cv. Fortuna produced the highest total fruit yield per plant as well as per feddan during the two seasons. Such differences in total fruit yield and its components among the studied cultivars may be attributed to the differences in genetical structure between such cultivars. Also such superiorty of cv. Fortuna in produced yield and its components are connected with the vigorous vegetative growth Table (1) and the higher 
uptake of macro-nutrients N, P and K Table (2) which in turn affect positively the producing ability of plants.

Obtained results are in the same line as those reported by $[4,22,13,28]$ all working on strawberry who reported great differences in total fruit yield and its components between the tested cultivars. However, [10 , 21] indicated that no significant differences among strawberry cultivars in the early and total yield.

\subsubsection{Effect of transplant roots dipping in methylotrophic bacteria}

With regard to the effect of transplant roots dipping in methylotrophic bacteria at $10 \mathrm{~cm}^{3} / 1$ concentration, data in Table (3) indicate that dipping the seedling roots pre transplantig in methylotrophic bacteria significantly increased all studied yield parameters compared with without dipping treatment during the two seasons of growth except the early yield per feddan during the first season only which did not reach the level of significance. Effects of inoculation with methylotrophic bacteria on plant growth through producing plant growth regulators like ziatin and related cytokinins and auxins [24]. and increased solubization and uptake of nutrints Table (2) and also phytohormone synthesis [7] which affect vegetative growth and in turn affect positively fruit yield and its components.

\subsubsection{Effect of number of foliar sprays with methylotrophic bacteria}

Data presented in Table (3) show that total produced fruit yield and its components were significantly affected as a result of foliar spray treatments. In this respect, spraying plants six times during the growing season starting after 20 days from transplanting and every 15 days by intervals significantly increased early yield and total fruit yield for both plant and feddan as well as marketable fruit yield feddan ${ }^{-1}$, however it decreased the unmarketable fruit yield compared with other tested treatments and the control in both seasons of study. Moreover, such increases in total fruit yield and its components as a result of foliar spraying treatments are connected with increasing the vegetative growth traits Table (1) and increasing the chemical constituents of plant foliage Table (2) which in turn affect positively produced yield. Obtained results are similar to those reported by $[27,6,3$ ] who found that pre harvest application of yeast and methylotrophic bacteria positively affected fruit yield and its components.

\subsubsection{Effect of the interaction}

Concerning the effect of the interaction between cultivars and transplant roots dipping in methylotrophic bacteria at $10 \mathrm{~cm}^{3} / 1$ concentration, data in Table (3) show that there were significant differences between interaction treatments for all fruit yield and its components during the two seasons of growth. In this respect, the highest values in all fruit yield and its components were recorded as a result of using the interaction treatment between cv. Fortuna combined with dipping transplants roots in methylotrophic bacteria at $10 \mathrm{~cm}^{3} / 1$ concentration, except unmarketable fruit yield during the two seasons of growth which exhibit the highest values with using the interaction treatment between cv. Fortuna without dipping seedling roots in methylotrophic bacteria. Meanwhile, the lowest values of unmarketable fruit yield were recorded by using the interaction treatment between cv. Sweet Charlie and dipping seedling roots in methylotrophic bacteria.

As for the effect of the interaction between dipping of transplants and number of foliar sprays with methylotrophic bacteria at $10 \mathrm{~cm} 3 / 1$ concentration, data in Table (3) reveal that there were significant differences in total fruit yield and its components as affected by the interaction treatments compared with the control. In addition, the highest values were noticed in case of using the interaction treatment between dipping plant roots in methylotrophic bacteria and spraying plants six times during the growth season starting after 20 days from transplanting and every 15 days by intervals by the same bacteria followed by the interaction treatment between dipping of seedling roots combined with four times foliar spray as well as without dipping and six times foliar spray without any significant differences between them for fruit yield per plant, early yield per feddan, marketable yield and total fruit yield per feddan during the two seasons of growth. Whereas, the same interaction treatments that mentioned above gave the lowest values for unmarketable fruit yield compared with the control and other interaction treatments.

With regard to the effect of the interaction treatments between cultivars and number of foliar sprays with methylotrophic bacteria at $10 \mathrm{~cm}^{3} / 1$ concentration, the same data in Table (3) show clearly that fruit yield and its components, were significantly affected by the interaction treatments. In this connection, using cv. Fortuna combined with foliar spraying the plants six times during the growing season by using methylotrophic bacteria at $10 \mathrm{~cm}^{3} / 1$ concentration recorded the highest values of yield and its components under study, followed by using the interaction treatment cv. Fortuna and four times foliar spray. On the other hand, the highest unmarketable fruit yield was obtained from using the control treatment followed by the interaction treatment between $\mathrm{cv}$. Fortuna and foliar spray the plants two times during the growth season.

Regarding the effect of interaction treatments between each of cultivars, transplant roots dipping 
and number of foliar sprays with methylotrophic bacteria at $10 \mathrm{~cm}^{3} / 1$ concentration, data in Table (3) indicate that all fruit yield and its components traits were significantly increased as a result of all interaction treatments compared with the control during the two growth seasons. Moreover, using cv. Fortuna and dipping of seedling roots in methylotrophic bacteria as well as foliar spraying the plants six times with the same bacteria during the growth season starting after 20 days from transplanting and every 15 days by intervals recorded the highest values for most fruit yield components followed by cv. Fortuna with dipping seedling roots and four times foliar spray as well as the interaction treatment between cv. Fortuna and without dipping of seedlings roots with six times foliar spray during the growth season. On the other hand, the lowest unmarketable fruit yield was obtained from using the interaction treatment of $\mathrm{cv}$. Sweet Charlie and dipping of seedling roots combined with six times foliar spray during the growth season followed by cv. Fortuna and dipping of seedling roots before transplanting with six times foliar spray with methylotrophic bacteria.

\subsection{Fruit quality}

\subsubsection{Physical fruit quality}

\subsubsection{Effect of cultivars}

Concerning the effect of tested cultivars on physical fruit quality and its components, data in Table (4) indicate that physical fruit quality expressed as average fruit weight, length, diameter and firmness were significantly differed among the tested cultivars. In this respect, cv. Fortuna recorded the highest values in all assayed physical fruit quality except average fruit length which was not differ among cv Sweet Charlie during both growth seasons. In this connection, such differences in physical fruit quality among the studied cultivars may be attributed to the effect of genetic factors affecting physical fruit quality parameters. Obtained results are similar to those reported by [4, $22,13,28]$.

\subsubsection{Effect of transplant roots dipping in methylotrophic bacteria}

As for the effect of transplant roots dipping in methylotrophic bacteria at $10 \mathrm{~cm}^{3} / 1$ concentration, data in Table (4) reveal that there were significant differences among dipping and without dipping treatments in all measured physical fruit quality traits during both seasons of study except average fruit length in the first season and average fruit diameter in the second one which did not reach the $5 \%$ level of significance. In this regard, pre transplanting seedling dipping in methylotrophic bacteria at $10 \mathrm{~cm}^{3} / 1$ concentration exhibited the highest values in all measured physical fruit quality of strawberry compared with the control (without dipping) treatment.
3.4.1.3 Effect of number of foliar sprays with methylotrophic bacteria

With regard to the effect of number of foliar sprays with methylotrophic bacteria at $10 \mathrm{~cm}^{3} / 1$ concentration, which starting after 20 days from transplanting dates and every 15 days by intervals on physical fruit quality of strawberry, data in Table (4) reveal that there were significant differences among the used number of foliar spraying treatments in all measured physical fruit quality compared with the control treatment during both seasons of growth. In this regard, spraying plants with methylotrophic bacteria six times show the highest values for all physical fruit quality expressed as average fruit weight, length, diameter and firmness during both seasons of study. This results were true during both seasons of growth.

Obtained results are going in line with those reported by [2, 11, 3 ] in case of using yeast extract and methylotrophic bacteria.

\subsubsection{Effect of the interaction}

As for the effect of the interaction between cultivars and transplants roots dipping in methylotrophic bacteria at $10 \mathrm{~cm}^{3} / 1$ concentration, data in Table (4) indicate that there were significant differences in all physical fruit quality due to the interaction between the two studied factors except fruit length in the two seasons of growth which did not reach the $5 \%$ level of significance. In this respect, Fortuna cultivars combined with dipping transplants roots in methylotrophic bacteria reflected the highest values for average fruit weight, length, diameter and firmness. Meanwhile, dipping seedling roots of Sweet Charlie cultivar before transplanting in methylotrophic bacteria reflected the highest values for fruit length during the second season of growth only.

With regard to the interaction between dipping roots transplants and number of foliar sprays with methylotrophic bacteria at $10 \mathrm{~cm}^{3} / 1$ concentration , data in Table (4) show that there were significant differences in all physical fruit quality traits due to the interaction between the two studied factors. Obtained results are true during the both seasons of study. In this respect, the highest values were recorded as a result of dipping seedling roots of strawberry and foliar spray six times with methylotrophic bacteria at $10 \mathrm{~cm}^{3} / 1$ concentration for all physical fruit quality followed by the interaction between dipping with four times of foliar spray and the interaction between without dipping with six times of foliar spray without any significant differences between them for all physical fruit quality and its components.

Refering to the effect of the interaction between the cultivars and number of foliar sprays with methylotrophic bacteria at $10 \mathrm{~cm}^{3} / 1$ concentration, data in Table (4) show that average fruit weight, length, diameter and firmness were significantly 
affected due to the interaction between the tested cultivars and number of foliar sprays with methylotrophic bacteria. In this respect, the highest fruit weight, length, diameter and firmness were noticed in case of cv. Fortuna and six times of foliar sprays during both seasons of growth followed by the interaction treatment among cv. Fortuna and four times of foliar sprays with methylotrophic bacteria as well as the interaction treatment between cv. Fortuna and two times of foliar sprays with the same bacteria during the second season only.

Concerning the interaction between each of cultivars, seedling roots dipping and number of foliar sprays with methylotrophic bacteria at 10 $\mathrm{cm}^{3} / 1$ concentration, data in the same Table reveal that there were significant differences between all interaction treatments for all physical fruit quality during both seasons of study. Meanwhile, average fruit length during the first season did not reach the $5 \%$ level of significance. In this regard, the best interaction treatment which gave the highest values for the average fruit weight, length, diameter and firmness were the interaction between Fortuna cultivar combined with dipping transplants roots pre transplanting in methylotrophic bacteria and plants foliar spray six times with methylotrophic bacteria at $10 \mathrm{~cm}^{3} / 1$ concentration.

\subsubsection{Chemical fruit quality \\ 3.4.2.1 Effect of cultivars}

Concerning the effect of tested cultivars on chemical fruit quality, data in Table (5) indicate that TSS, total sugars and anthocyanin differed significantly among the tested cultivars. Meanwhile, vitamin- $\mathrm{C}$ and total acidity did not reach the $5 \%$ level of significance during the two seasons of growth. In this respect, cv Sweet Charlie recorded the highest values in all assayed chemical fruit quality compared with cv. Fortuna during both growth seasons. In this connection, such differences in the content of estimated mineral and organic constituents of produced fruits were connected with higher chemical constituents of plant foliage (Table, 2) which in turn affected fruit chemical composition. Also, such differences in chemical fruit quality between the studied cultivars may be attributed to the genetic structure of such cultivars. Obtained results are in agreement with those reported by $[4,13,28]$ all working on strawberry.

\subsubsection{Effect of transplant roots dipping in methylotrophic bacteria}

As for the effect of transplant roots dipping in methylotrophic bacteria at $10 \mathrm{~cm}^{3} / 1$ concentration, data in Table (5) reveal that there were significant differences among dipping and without dipping treatments in chemical fruit quality, i.e., total sugars and anthocyanin concentration during both seasons of study. Moreover, total soluble solids, vitamin-C and total acidity did not reach the $5 \%$ level of significance during both seasons of growth. In this regard, dipping strawberry seedling roots before transplanting in methylotrophic bacteria at $10 \mathrm{~cm}^{3} / 1$ concentration exhibited the highest values in all studied chemical fruit quality of strawberry compared with or without dipping treatments.

\subsubsection{Effect of number of foliar sprays with methylotrophic bacteria}

With regard to the effect of number of foliar sprays with methylotrophic bacteria at $10 \mathrm{~cm}^{3} / 1$ concentration which starting after 20 days from transplanting dates and every 15 days by intervals on chemical fruit quality of strawberry, data in Table (5) reveal that there were significant differences among the used number of foliar

spraying treatments in all measured chemical fruit quality compared with the control treatment during both seasons of growth except TSS and vitamin- $\mathrm{C}$ during the first season and total acidity during the second one which did not reach the $5 \%$ level of significance. In this regard, foliar spraying plants with methylotrophic bacteria at $10 \mathrm{~cm}^{3} / 1$ concentration six times show the highest values for all chemical fruit quality during both seasons of study. These results were true during the both seasons of growth. In this concept [29, 3 ] came to similar conclusion in case of using yeast extract and methylotrophic bacteria.

\subsubsection{Effect of the interaction}

As for the effect of the interaction between cultivars and transplant roots dipping in methylotrophic bacteria at $10 \mathrm{~cm}^{3} / 1$ concentration, data in Table (5) indicate that there were significantly differences in all chemical fruit quality due to the interaction between the two studied factors except vitamin-C and total acidity concentration in the two seasons of study which did not reach the $5 \%$ level of significance. In this respect, Sweet Charlie cultivar with dipping plant roots in methylotrophic bacteria at $10 \mathrm{~cm}^{3} / 1$ concentration reflected the highest values for vitamin-C, total acidity, total sugars and anthocyanin concentration during the two seasons of growth.

With regard to the interaction between dipping of transplant roots and number of foliar sprays with methylotrophic bacteria at $10 \mathrm{~cm}^{3} / 1$ concentration, data in Table (5) show that there were significant differences in all chemical fruit quality traits due to the interaction between the two studied factors. Obtained results are true during the both seasons of study. While, TSS during the first season and TSS and total acidity during the second season did not reach the 5\% level of significance. In this respect, the highest values were recorded as a result of dipping seedling roots of strawberry before 
transplanting and foliar spray plants six times with methylotrophic bacteria at $10 \mathrm{~cm}^{3} / 1$ concentration for all chemical fruit quality followed by the interaction without dipping combined with six times of foliar spray and the interaction between dipping with four times of foliar spray without any significant differences between them for all chemical fruit quality.

Refering to the effect of the interaction between the cultivars and number of foliar sprays with methylotrophic bacteria at $10 \mathrm{~cm}^{3} / 1$ concentration, data in Table (5) show that the TSS, vitamin-C, total acidity, total sugars and anthocyanin concentration were significantly affected due to the interaction between the tested cultivars and number of foliar sprays with methylotrophic bacteria. Moreover, vitamin- $\mathrm{C}$ during the first season and total acidity during the second one did not reach the $5 \%$ level of significance. In this respect, the highest TSS, vitamin-C, total acidity, total sugars and anthocyanin concentration were noticed mostly in case of cv. Sweet Charlie and six times of foliar sprays during both seasons.
Concerning the interaction between each of cultivars, dipping seedling roots and number of foliar sprays with methylotrophic bacteria at 10 $\mathrm{cm}^{3} / 1$ concentration starting after 20 days from transplanting and every 15 days by intervals, data in the same Table reveal that there were significant differences between all interaction treatments for all chemical fruit quality during both seasons of study. whereas, vitamin-C during the first season and total acidity during the second one did not reach the level of significance. In this regard, the best interaction treatment which gave the highest values for TSS, vitamin-C, total acidity, total sugars and anthocyanin concentration were between Sweet Charlie cultivar combined with dipping and foliar spray six times with methylotrophic bacteria at 10 $\mathrm{cm}^{3} / 1$ except vitamin-C and total acidity during the second season of growth, whereas, the interaction between Fortuna cultivar with dipping and foliar spray six times with methylotrophic bacteria reflected the highest values for vitamin- $\mathrm{C}$ and total acidity during the second season of growth.

\section{Conclusion}

Under such condition it could be concluded that planting cv. Fortuna with dipping seedling roots before transplanting for 10 minutes in methylotrophic bacteria solution at $10 \mathrm{~cm}^{3} / 1$ combined with foliar spraying plants six times with the same bacteria starting after 20 days from transplanting and every 15 days by intervals during the growing season was recommended to obtaining good Vegetative growth and higher fruit yield with best quality. 


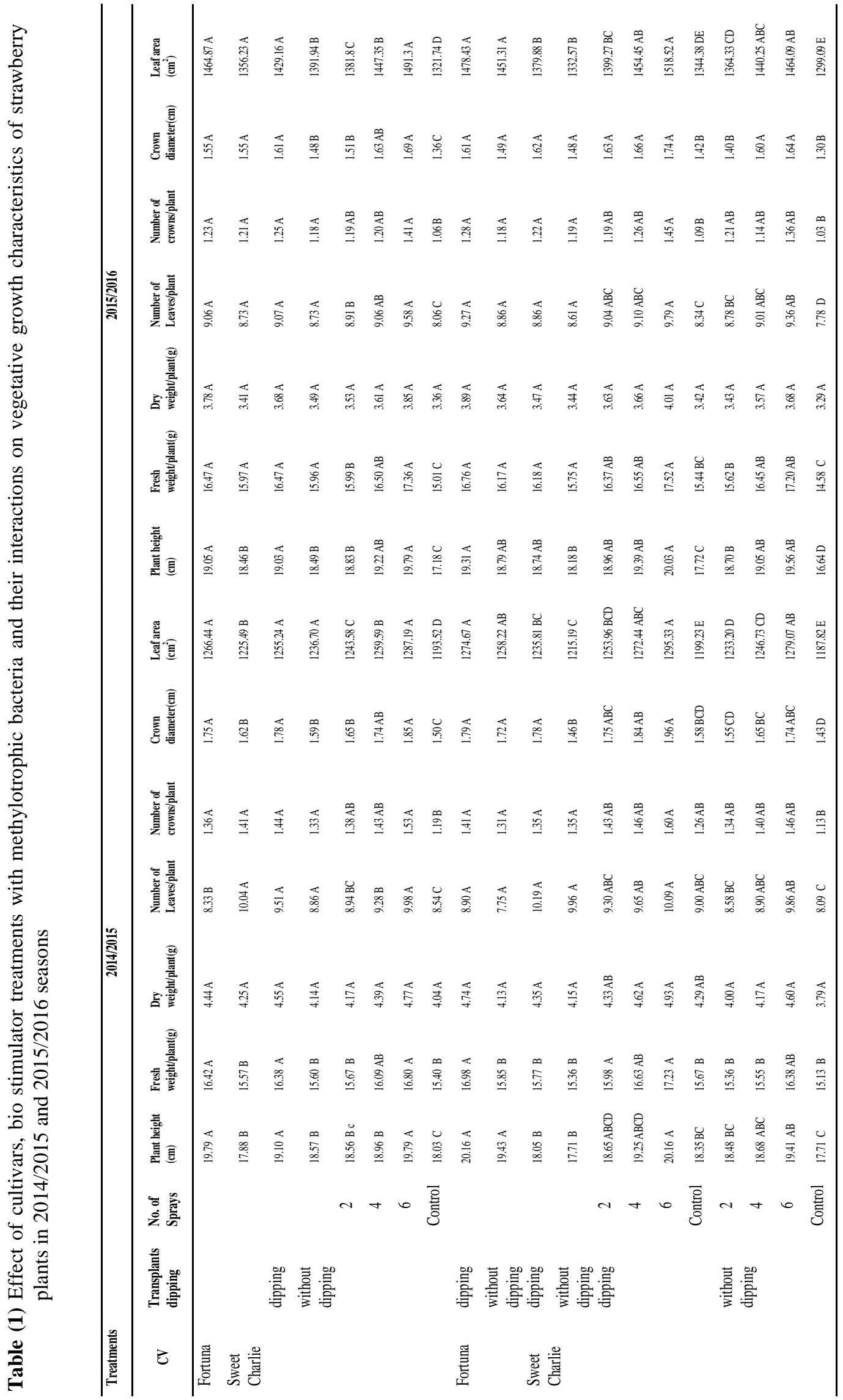




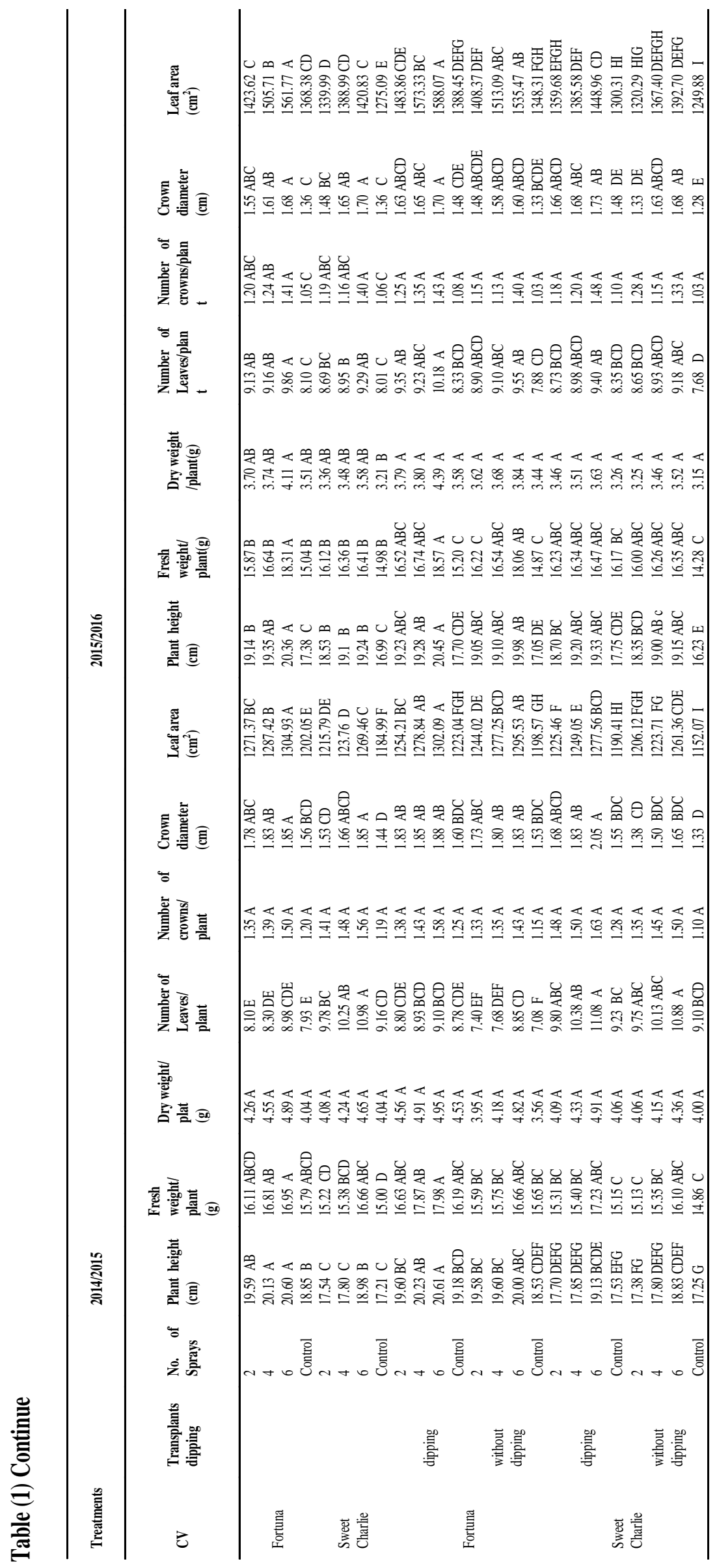




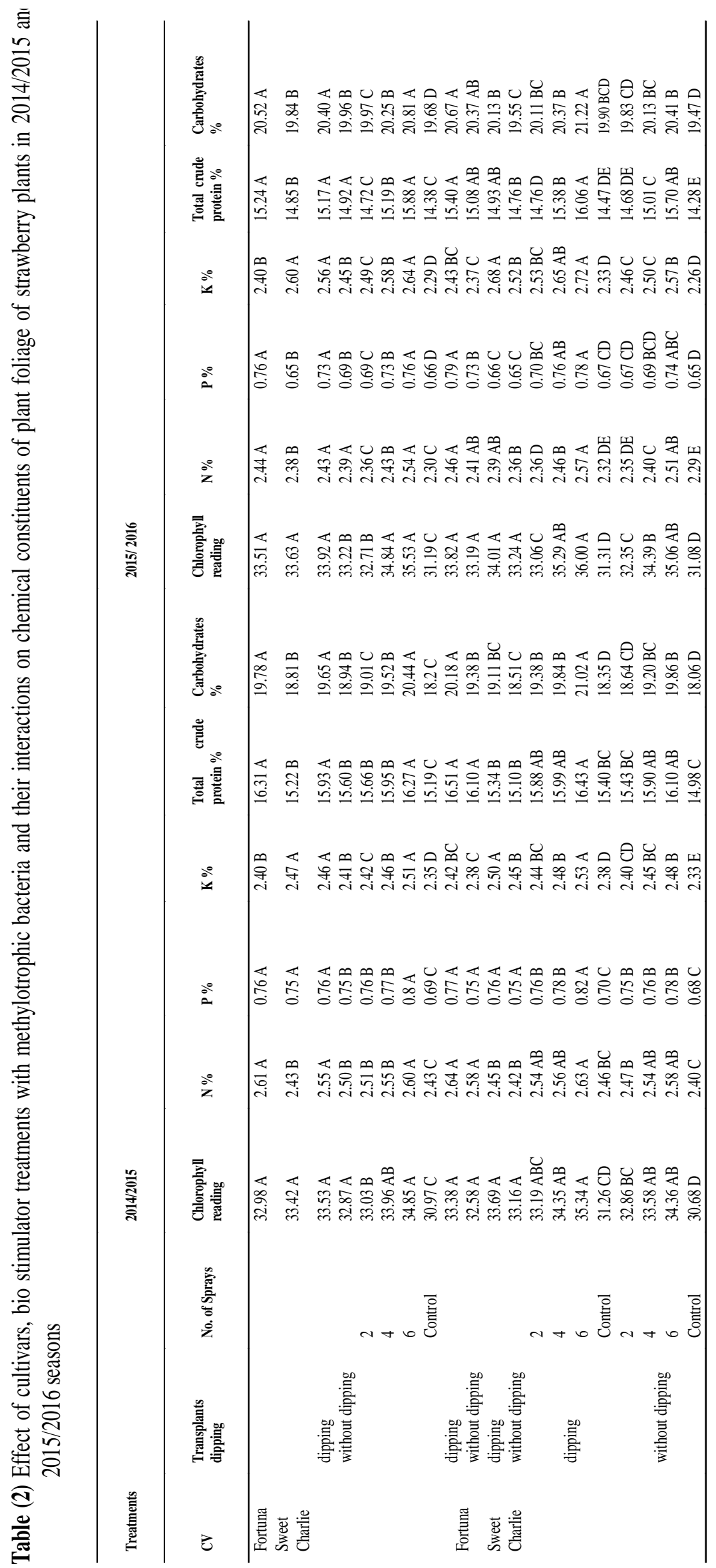




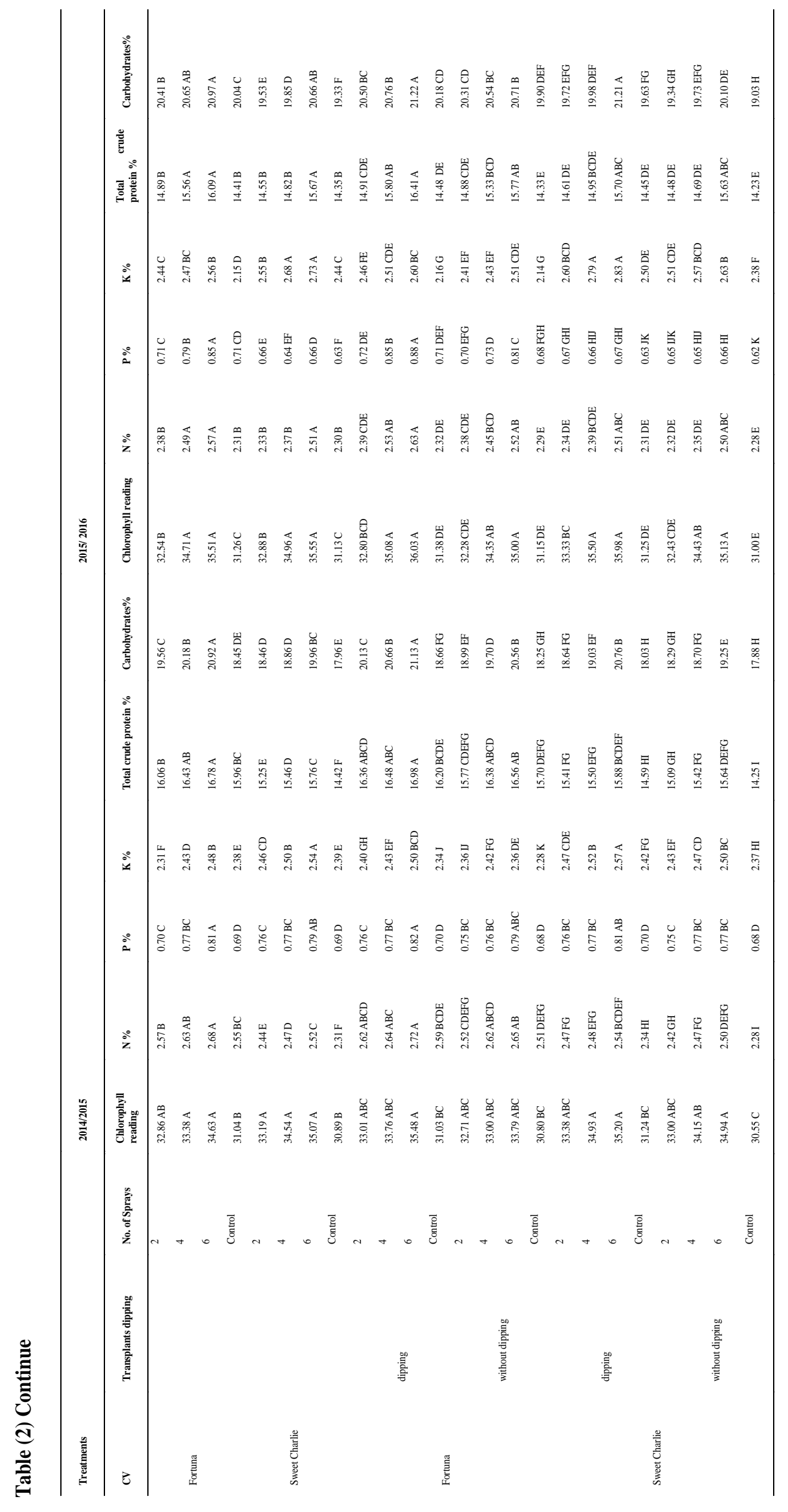




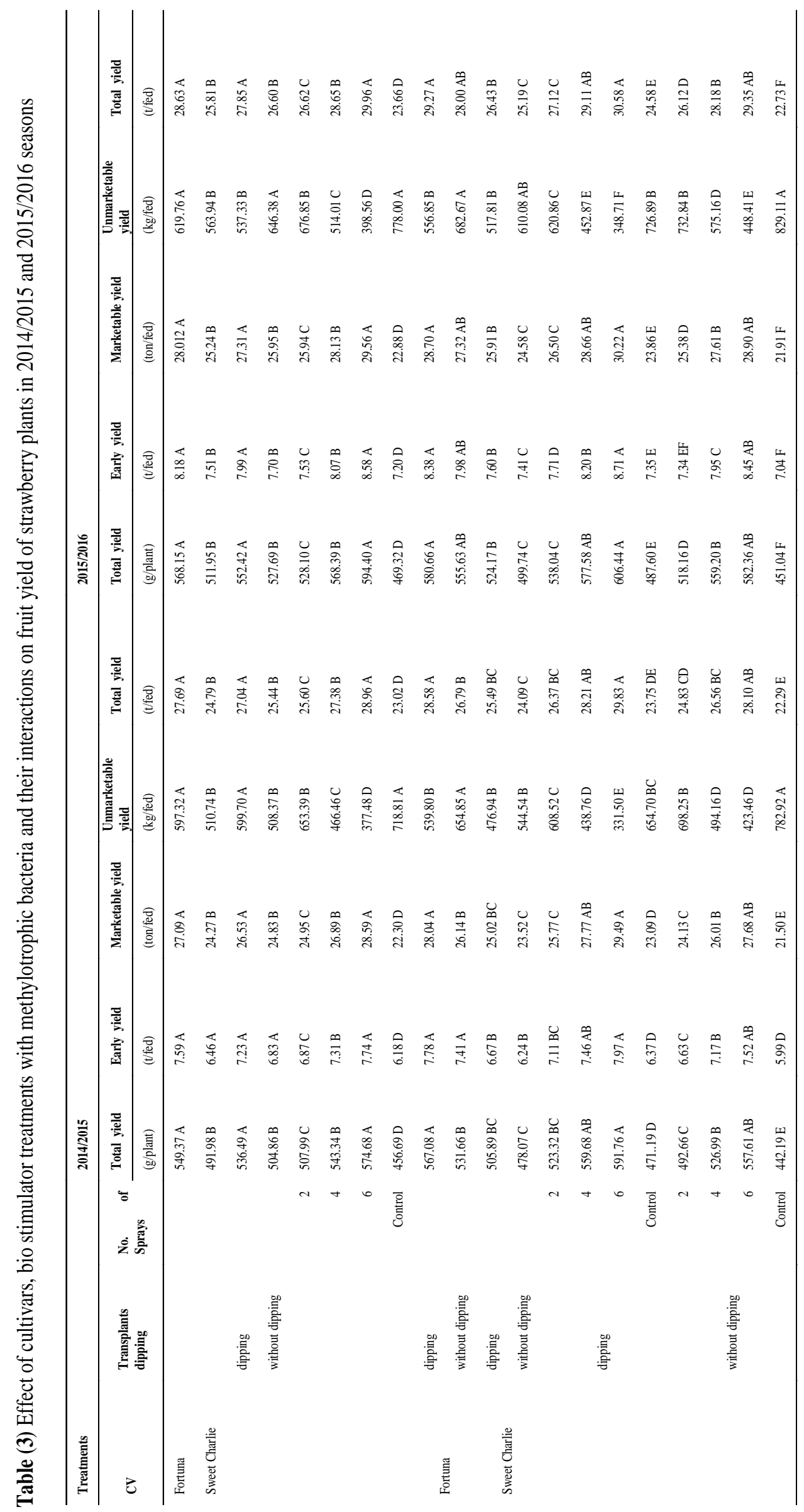




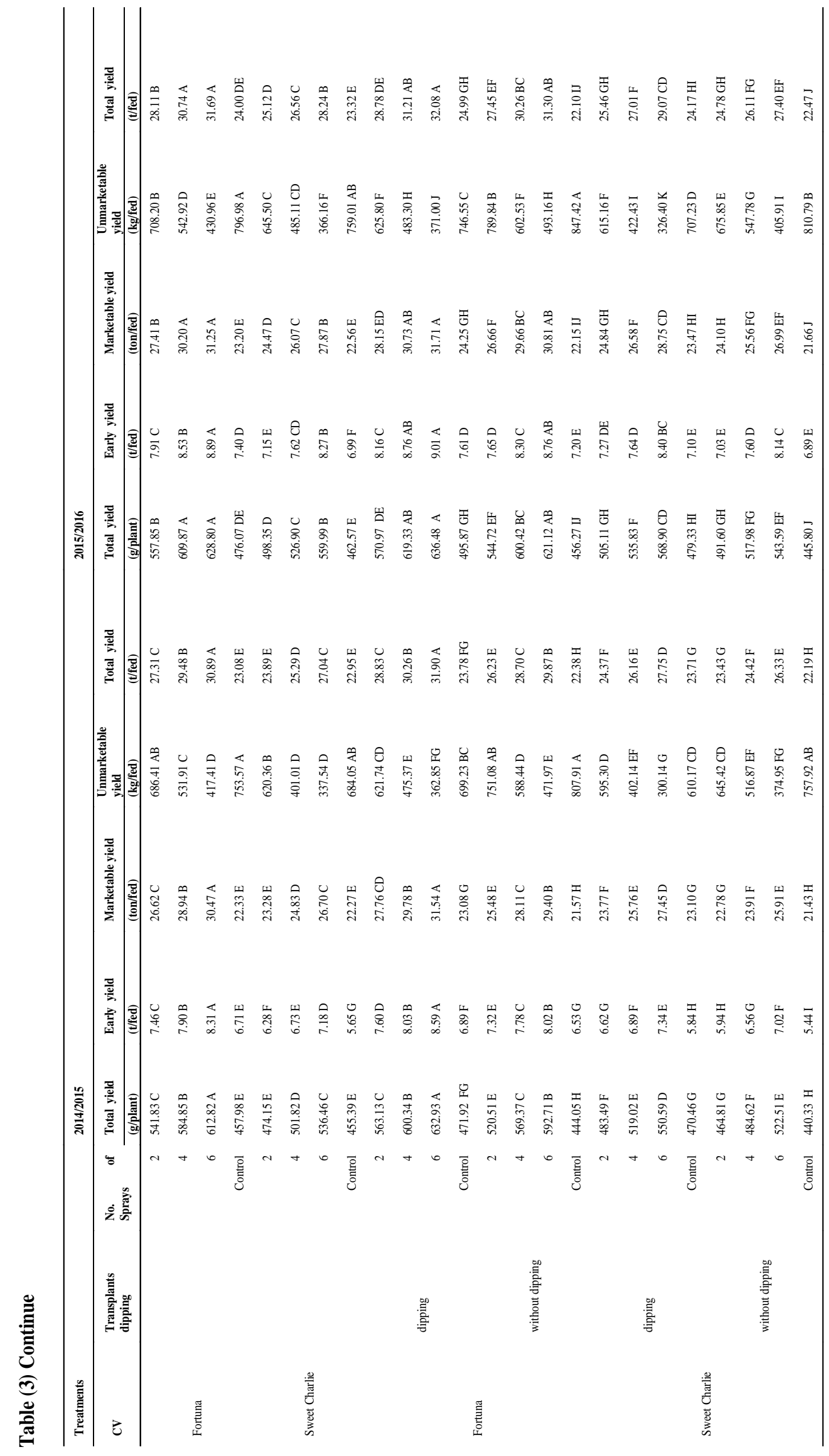




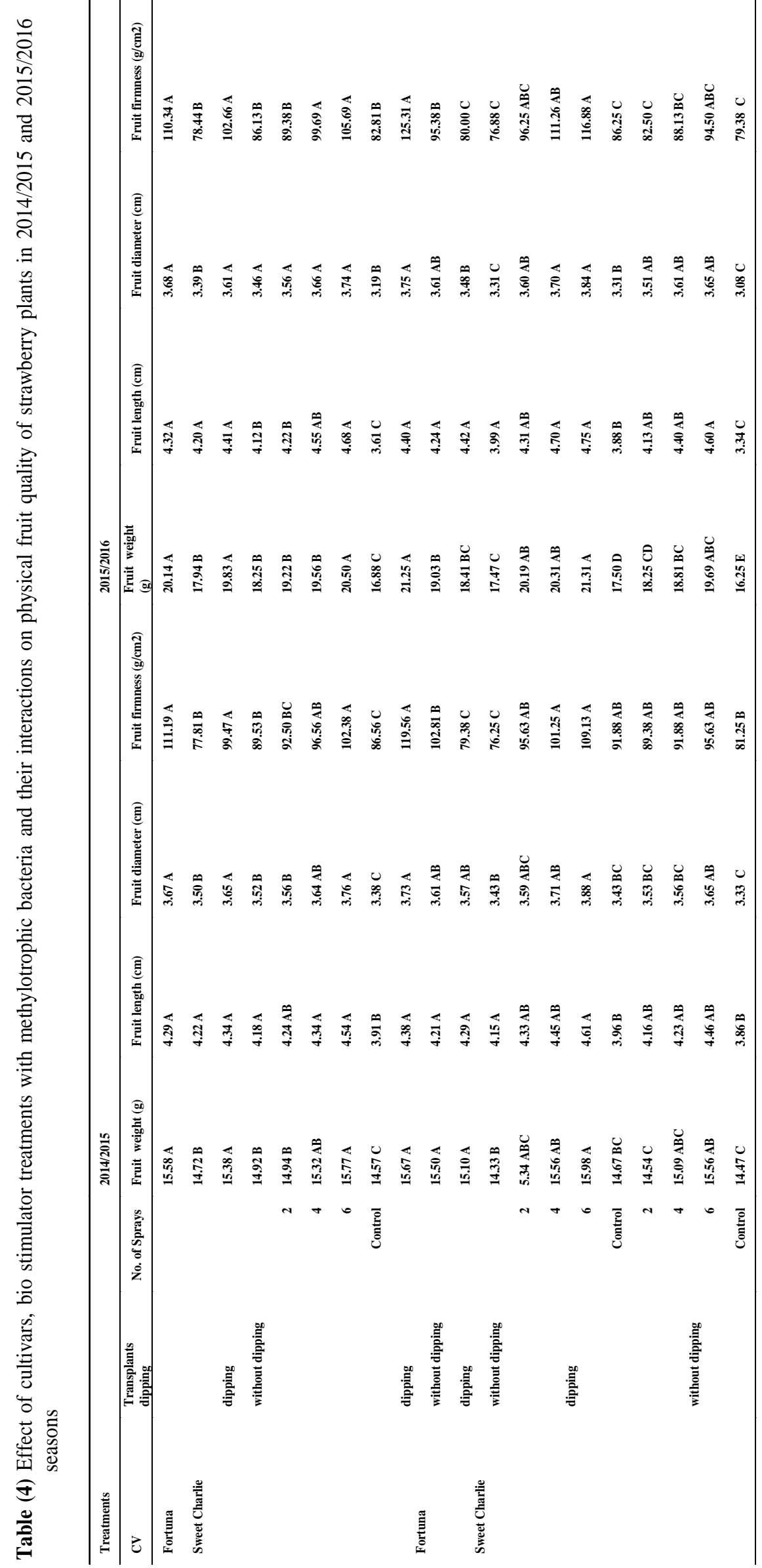




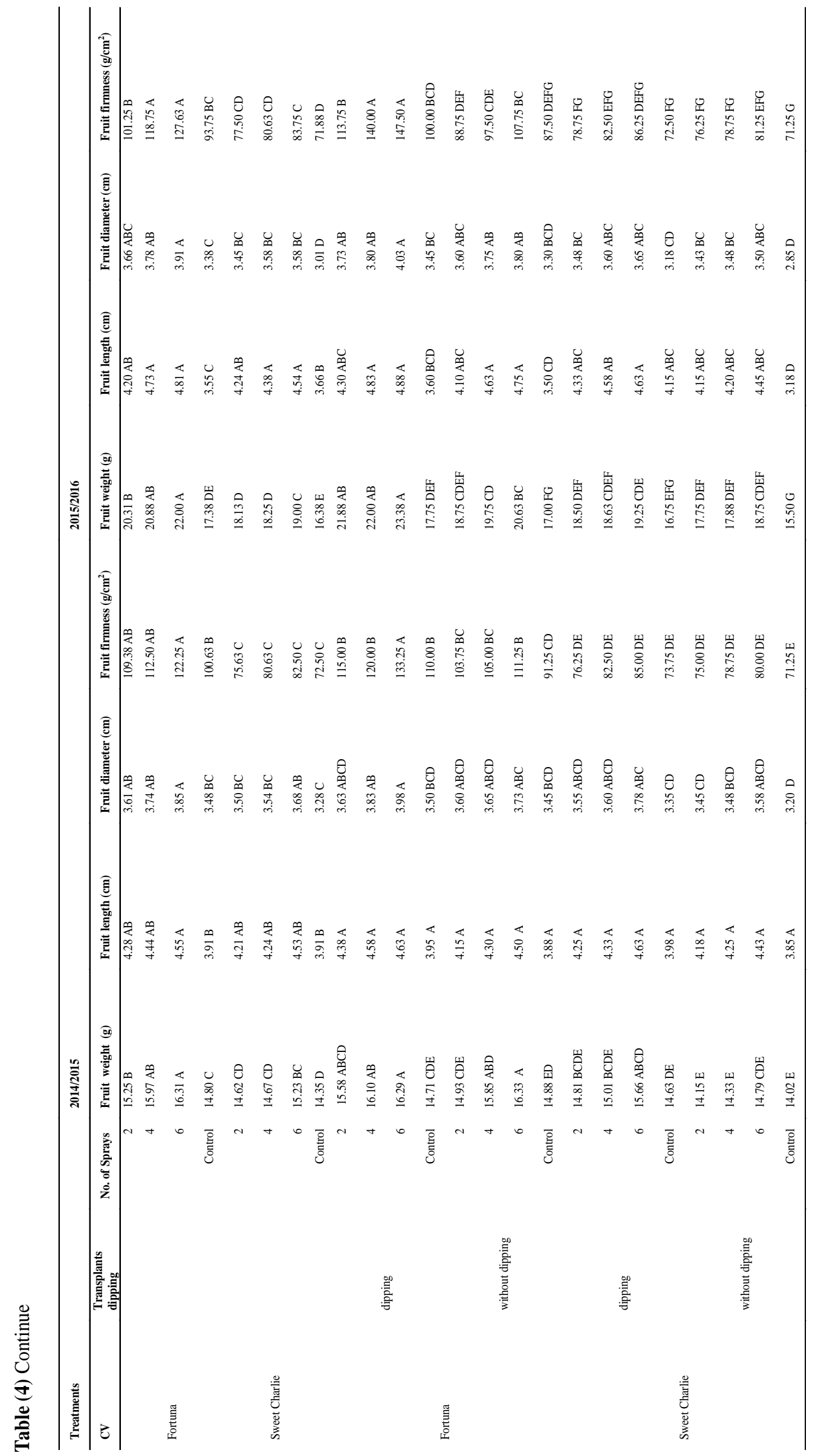




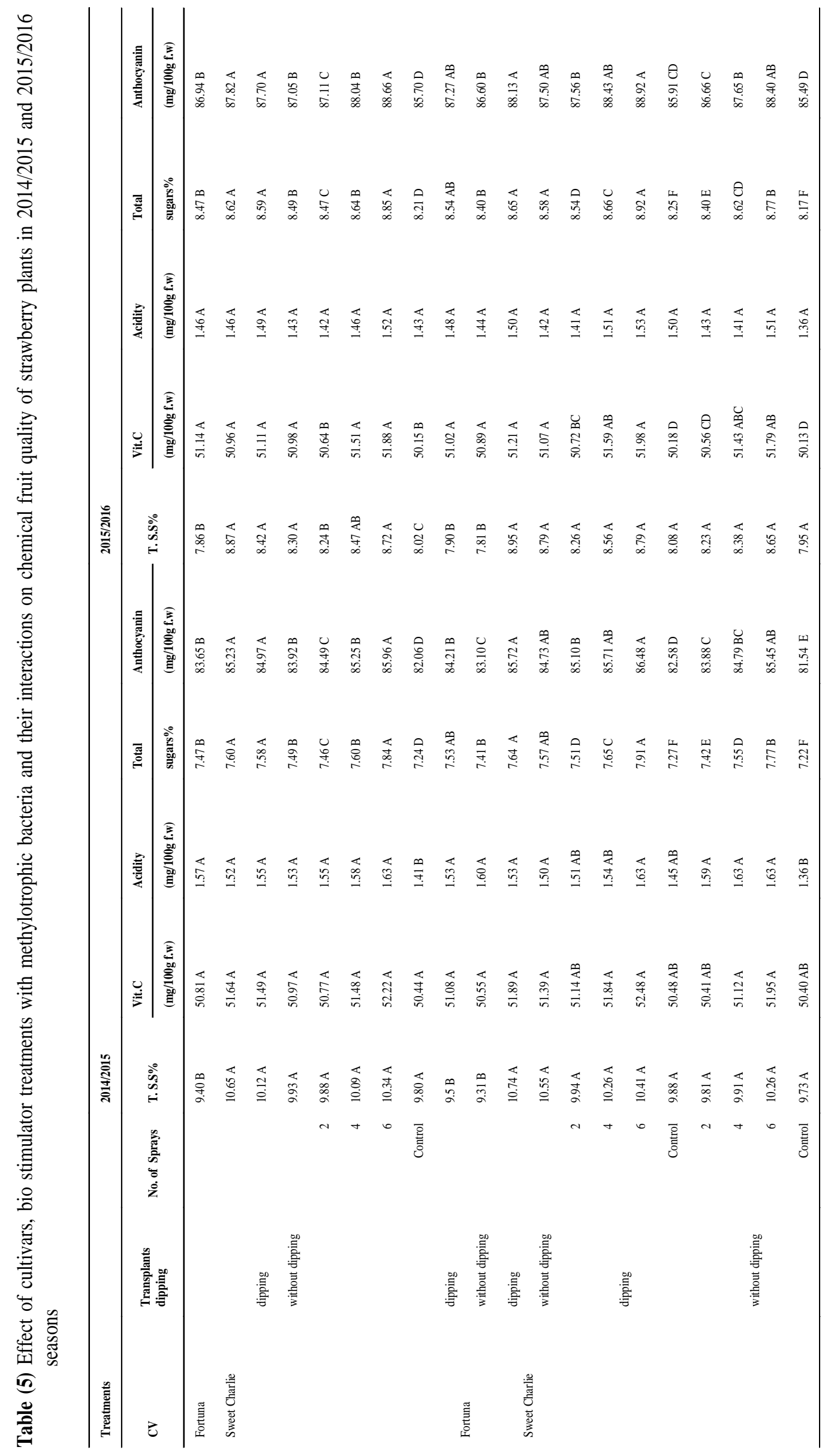


Table (5) Continue

\begin{tabular}{|c|c|c|c|c|c|c|c|c|c|c|c|c|}
\hline Treatments & & & $2014 / 201$ & & & & & $2015 / 2016$ & & & & \\
\hline \multirow{2}{*}{ CV } & \multirow{2}{*}{$\begin{array}{l}\text { Transpl } \\
\text { ants } \\
\text { dipping }\end{array}$} & \multirow{2}{*}{$\begin{array}{l}\text { No. of } \\
\text { Spray } \\
\mathrm{s}\end{array}$} & \multirow{2}{*}{$\begin{array}{l}\text { T. } \\
\text { S.S\% }\end{array}$} & \multirow{2}{*}{$\begin{array}{l}\text { Vit.C } \\
\text { (mg/10 } \\
\text { Og f.w) }\end{array}$} & \multirow{2}{*}{$\begin{array}{l}\text { Acidity } \\
(\mathrm{mg} / 100 \\
\mathrm{g} \text { f.w })\end{array}$} & \multirow{2}{*}{$\begin{array}{l}\text { Total } \\
\text { sugars } \\
\%\end{array}$} & \multirow{2}{*}{$\begin{array}{l}\begin{array}{l}\text { Anthocy } \\
\text { anin }\end{array} \\
\text { (mg/100 } \\
\text { g f.w) }\end{array}$} & \multirow{2}{*}{ T.S.S\% } & \multirow{2}{*}{$\begin{array}{l}\text { Vit.C } \\
\text { (mg/100g } \\
\text { f.w) }\end{array}$} & \multirow{2}{*}{$\begin{array}{l}\text { Acidity } \\
(\mathrm{mg} / \mathbf{1 0 0} \\
\text { g f.w) }\end{array}$} & \multirow{2}{*}{$\begin{array}{l}\text { Total } \\
\text { sugars \% }\end{array}$} & \multirow{2}{*}{$\begin{array}{l}\begin{array}{l}\text { Anthocy } \\
\text { anin }\end{array} \\
(\mathrm{mg} / \mathbf{1 0 0} \\
\mathrm{g} \text { f.w })\end{array}$} \\
\hline & & & & & & & & & & & & \\
\hline \multirow{4}{*}{ Fortuna } & & 2 & $9.31 \mathrm{~B}$ & $\begin{array}{l}50.13 \\
\text { A }\end{array}$ & $1.60 \mathrm{AB}$ & $7.42 \mathrm{E}$ & $83.73 \mathrm{E}$ & $7.73 \mathrm{E}$ & $50.16 \mathrm{~B}$ & $1.39 \mathrm{~A}$ & $8.80 \mathrm{~B}$ & $86.61 \mathrm{C}$ \\
\hline & & 4 & $9.43 \mathrm{~B}$ & $\begin{array}{l}51.20 \\
\mathrm{~A}\end{array}$ & $1.61 \mathrm{AB}$ & $7.57 \mathrm{D}$ & $84.44 \mathrm{DE}$ & $7.89 \mathrm{E}$ & $51.52 \mathrm{~A}$ & $1.46 \mathrm{~A}$ & $8.60 \mathrm{E}$ & 87.92 B \\
\hline & & 6 & $9.63 \mathrm{~B}$ & $\begin{array}{l}51.81 \\
\mathrm{~A}\end{array}$ & $1.64 \mathrm{~A}$ & $7.77 \mathrm{~B}$ & $\begin{array}{l}84.89 \\
\mathrm{CD}\end{array}$ & $8.16 \mathrm{D}$ & $52.07 \mathrm{~A}$ & $1.60 \mathrm{~A}$ & $8.77 \mathrm{C}$ & $\begin{array}{l}88.39 \\
\mathrm{AB}\end{array}$ \\
\hline & & $\begin{array}{r}\text { Contro } \\
1\end{array}$ & $9.25 \mathrm{~B}$ & $\begin{array}{l}50.11 \\
\text { A }\end{array}$ & $1.41 \mathrm{~B}$ & $7.13 \mathrm{G}$ & $81.56 \mathrm{G}$ & $7.65 \mathrm{E}$ & $50.07 \mathrm{~B}$ & $1.38 \mathrm{~A}$ & $8.11 \mathrm{G}$ & $84.83 \mathrm{D}$ \\
\hline \multirow{4}{*}{$\begin{array}{l}\text { Sweet } \\
\text { Charlie }\end{array}$} & & 2 & $10.44 \mathrm{~A}$ & $\begin{array}{l}51.42 \\
\mathrm{~A}\end{array}$ & $1.50 \mathrm{AB}$ & $7.51 \mathrm{D}$ & $85.25 \mathrm{C}$ & $8.76 \mathrm{~B}$ & $51.11 \mathrm{AB}$ & $1.45 \mathrm{~A}$ & $8.55 \mathrm{E}$ & $87.60 \mathrm{~B}$ \\
\hline & & 4 & $10.75 \mathrm{~A}$ & $\begin{array}{l}51.76 \\
\mathrm{~A}\end{array}$ & $1.55 \mathrm{AB}$ & $7.63 \mathrm{C}$ & $86.06 \mathrm{~B}$ & $9.05 \mathrm{AB}$ & $51.49 \mathrm{~A}$ & $1.46 \mathrm{~A}$ & $8.68 \mathrm{D}$ & $\begin{array}{l}88.16 \\
\mathrm{AB}\end{array}$ \\
\hline & & 6 & $11.05 \mathrm{~A}$ & $\begin{array}{l}52.63 \\
\text { A }\end{array}$ & $1.61 \mathrm{AB}$ & $7.91 \mathrm{~A}$ & $87.03 \mathrm{~A}$ & $9.28 \mathrm{~A}$ & $51.70 \mathrm{~A}$ & $1.44 \mathrm{~A}$ & $8.93 \mathrm{~A}$ & $88.93 \mathrm{~A}$ \\
\hline & & $\begin{array}{r}\text { Contro } \\
1\end{array}$ & $10.35 \mathrm{~A}$ & $\begin{array}{l}50.77 \\
\text { A }\end{array}$ & $1.40 \mathrm{~B}$ & $7.35 \mathrm{~F}$ & $82.56 \mathrm{~F}$ & $8.39 \mathrm{C}$ & $50.23 \mathrm{~B}$ & $1.49 \mathrm{~A}$ & $8.31 \mathrm{~F}$ & $86.57 \mathrm{C}$ \\
\hline \multirow{8}{*}{ Fortuna } & \multirow{4}{*}{ dipping } & 2 & $9.38 \mathrm{BC}$ & $\begin{array}{l}50.41 \\
\text { A }\end{array}$ & $1.53 \mathrm{~A}$ & $7.46 \mathrm{G}$ & $84.41 \mathrm{FG}$ & $7.70 \mathrm{FG}$ & $\begin{array}{l}50.30 \\
\mathrm{ABC}\end{array}$ & $1.33 \mathrm{~A}$ & $8.47 \mathrm{G}$ & $\begin{array}{l}87.14 \\
\text { CDE }\end{array}$ \\
\hline & & 4 & $9.53 \mathrm{BC}$ & $\begin{array}{l}51.73 \\
\mathrm{~A}\end{array}$ & $1.53 \mathrm{~A}$ & $7.62 \mathrm{CD}$ & $\begin{array}{l}84.93 \\
\text { DEF }\end{array}$ & $\begin{array}{l}7.98 \\
\text { EFG }\end{array}$ & $\begin{array}{l}51.58 \\
\mathrm{ABC}\end{array}$ & $1.56 \mathrm{~A}$ & 8.63 ED & $\begin{array}{l}88.20 \\
\text { ABC }\end{array}$ \\
\hline & & 6 & $9.73 \mathrm{BC}$ & $\begin{array}{l}52.04 \\
\text { A }\end{array}$ & $1.63 \mathrm{~A}$ & $7.90 \mathrm{~A}$ & $\begin{array}{l}85.31 \\
\text { CDE }\end{array}$ & $\begin{array}{l}8.23 \\
\text { CDEFG }\end{array}$ & $52.11 \mathrm{~A}$ & $1.63 \mathrm{~A}$ & $8.88 \mathrm{~B}$ & $\begin{array}{l}88.63 \\
\mathrm{AB}\end{array}$ \\
\hline & & $\begin{array}{r}\text { Contro } \\
1\end{array}$ & $9.38 \mathrm{BC}$ & $\begin{array}{l}50.14 \\
\text { A }\end{array}$ & $1.45 \mathrm{AB}$ & $7.16 \mathrm{~J}$ & $82.19 \mathrm{I}$ & $7.69 \mathrm{FG}$ & $50.11 \mathrm{BC}$ & $1.40 \mathrm{~A}$ & $8.17 \mathrm{~J}$ & $85.12 \mathrm{FG}$ \\
\hline & \multirow{4}{*}{$\begin{array}{l}\text { without } \\
\text { dipping }\end{array}$} & 2 & $9.25 \mathrm{BC}$ & $\begin{array}{l}49.85 \\
\mathrm{~A}\end{array}$ & $1.68 \mathrm{~A}$ & $7.39 \mathrm{H}$ & $83.04 \mathrm{H}$ & $7.75 \quad \mathrm{FG}$ & $50.04 \mathrm{C}$ & $1.45 \mathrm{~A}$ & $8.33 \mathrm{HI}$ & $86.09 \mathrm{EF}$ \\
\hline & & 4 & $9.33 \mathrm{BC}$ & $\begin{array}{l}50.67 \\
\text { A }\end{array}$ & $1.70 \mathrm{~A}$ & $7.51 \mathrm{~F}$ & $83.95 \mathrm{G}$ & $7.80 \quad \mathrm{FG}$ & $\begin{array}{l}51.47 \\
\mathrm{ABC}\end{array}$ & $1.38 \mathrm{~A}$ & $8.57 \mathrm{~F}$ & $\begin{array}{l}87.64 \\
\text { BCD }\end{array}$ \\
\hline & & 6 & $9.53 \mathrm{BC}$ & $\begin{array}{l}51.57 \\
\mathrm{~A}\end{array}$ & $1.65 \mathrm{~A}$ & $7.65 \mathrm{BC}$ & $84.47 \mathrm{FG}$ & $\begin{array}{l}8.10 \\
\text { DEFG }\end{array}$ & $52.03 \mathrm{AB}$ & $1.58 \mathrm{~A}$ & $8.66 \mathrm{CD}$ & $\begin{array}{l}88.14 \\
\mathrm{ABC}\end{array}$ \\
\hline & & $\begin{array}{r}\text { Contro } \\
1\end{array}$ & $9.13 \mathrm{C}$ & $\begin{array}{l}50.09 \\
\text { A }\end{array}$ & $1.38 \mathrm{~B}$ & $7.10 \mathrm{~K}$ & $80.95 \mathrm{~J}$ & $7.6 \mathrm{G}$ & $50.04 \mathrm{C}$ & $1.35 \mathrm{~A}$ & $8.05 \mathrm{~K}$ & $84.54 \mathrm{G}$ \\
\hline \multirow{8}{*}{$\begin{array}{l}\text { Sweet } \\
\text { Charlie }\end{array}$} & \multirow{4}{*}{ dipping } & 2 & $\begin{array}{l}10.50 \\
\mathrm{AB}\end{array}$ & $\begin{array}{l}51.87 \\
\mathrm{~A}\end{array}$ & $1.50 \mathrm{~A}$ & $7.57 \mathrm{E}$ & $85.79 \mathrm{BC}$ & $\begin{array}{l}8.83 \\
\mathrm{ABCD}\end{array}$ & $\begin{array}{l}51.15 \\
\mathrm{ABC}\end{array}$ & $1.50 \mathrm{~A}$ & $8.61 \mathrm{E}$ & $87.97 \mathrm{BC}$ \\
\hline & & 4 & $11.00 \mathrm{~A}$ & $\begin{array}{l}51.95 \\
\mathrm{~A}\end{array}$ & $1.55 \mathrm{~A}$ & $7.68 \mathrm{~B}$ & 86.48 B & $9.15 \mathrm{AB}$ & $\begin{array}{l}51.59 \\
\mathrm{ABC}\end{array}$ & $1.48 \mathrm{~A}$ & $8.70 \mathrm{C}$ & $\begin{array}{l}88.66 \\
\mathrm{AB}\end{array}$ \\
\hline & & 6 & $11.10 \mathrm{~A}$ & $\begin{array}{l}52.925 \\
\text { A }\end{array}$ & $1.63 \mathrm{~A}$ & $7.92 \mathrm{~A}$ & $87.64 \mathrm{~A}$ & $9.35 \mathrm{~A}$ & $\begin{array}{l}51.85 \\
\mathrm{ABC}\end{array}$ & $1.43 \mathrm{~A}$ & $8.96 \mathrm{~A}$ & $89.20 \mathrm{~A}$ \\
\hline & & $\begin{array}{r}\text { Contro } \\
1\end{array}$ & $\begin{array}{l}10.38 \\
\mathrm{AB}\end{array}$ & $\begin{array}{l}50.83 \\
\mathrm{~A}\end{array}$ & $1.45 \mathrm{AB}$ & $7.38 \mathrm{H}$ & $82.99 \mathrm{H}$ & $\begin{array}{l}8.48 \\
\text { BCDEF }\end{array}$ & $\begin{array}{l}50.24 \\
\mathrm{ABC}\end{array}$ & $1.60 \mathrm{~A}$ & $8.33 \mathrm{H}$ & $86.70 \mathrm{DE}$ \\
\hline & \multirow{4}{*}{$\begin{array}{l}\text { without } \\
\text { dipping }\end{array}$} & 2 & $\begin{array}{l}10.38 \\
\mathrm{AB}\end{array}$ & $\begin{array}{l}50.97 \\
\text { A }\end{array}$ & $1.50 \mathrm{~A}$ & $7.45 \mathrm{G}$ & $84.72 \mathrm{EF}$ & $\begin{array}{l}8.70 \\
\text { ABCDE }\end{array}$ & $\begin{array}{l}51.08 \\
\mathrm{ABC}\end{array}$ & $1.40 \mathrm{~A}$ & $8.48 \mathrm{G}$ & $\begin{array}{l}87.23 \\
\mathrm{CDE}\end{array}$ \\
\hline & & 4 & $\begin{array}{l}10.50 \\
\mathrm{AB}\end{array}$ & $\begin{array}{l}51.57 \\
\mathrm{~A}\end{array}$ & $1.55 \mathrm{~A}$ & $7.59 \mathrm{ED}$ & $\begin{array}{l}85.63 \\
\mathrm{CD}\end{array}$ & $\begin{array}{l}8.95 \\
\mathrm{ABC}\end{array}$ & $\begin{array}{l}51.40 \\
\mathrm{ABC}\end{array}$ & $1.45 \mathrm{~A}$ & $8.67 \mathrm{CD}$ & $\begin{array}{l}87.66 \\
\text { BCD }\end{array}$ \\
\hline & & 6 & $\begin{array}{l}11.00 \\
\mathrm{~A}\end{array}$ & $\begin{array}{l}52.33 \\
\mathrm{~A}\end{array}$ & $1.6 \mathrm{~A}$ & $7.89 \mathrm{~A}$ & 86.42 B & $9.20 \mathrm{AB}$ & $\begin{array}{l}51.56 \\
\mathrm{ABC}\end{array}$ & $1.45 \mathrm{~A}$ & $8.96 \mathrm{~B}$ & $\begin{array}{l}88.66 \\
\mathrm{AB}\end{array}$ \\
\hline & & $\begin{array}{r}\text { Contro } \\
1 \\
\end{array}$ & $\begin{array}{l}10.33 \\
\mathrm{ABC}\end{array}$ & $\begin{array}{l}50.71 \\
\mathrm{~A}\end{array}$ & $1.35 \mathrm{~B}$ & $7.33 \mathrm{I}$ & $82.14 \mathrm{I}$ & $\begin{array}{l}8.31 \\
\text { CDEFG }\end{array}$ & $\begin{array}{l}50.23 \\
\mathrm{ABC}\end{array}$ & $1.38 \mathrm{~A}$ & $8.29 \mathrm{I}$ & $86.44 \mathrm{E}$ \\
\hline
\end{tabular}

\section{References}

[1] A. O. A. C, Official and tentative methods of analysis. Association of Official Analytical Chemists. Washington, D.C,U.S.A, 1990.

[2] M. M. M. Abd El-All, Improvement of tomato productivity by using certain natural materials. Ph.D. Thesis. Fac. of Agric., Benha univ, 2009.

[3] H. G. Abd El-Gawad, M. F. M. Ibrahim, A. A. Abd El-Hafez, A. Abou El-Yazied, Contribution of Pink Pigmented Facultative Methylotrophic Bacteria in Promoting Antioxidant Enzymes, Growth and Yield of Snap Bean. AmericanEurasian J. Agric. \& Environ. Sci., vol.15 (7), pp. 1331-1345, 2015.

[4] R. E. Ahmed, Response of some new strawberry genotypes to cultivation under plastic tunnels. M.Sc. Thesis, Fac of Agric., Ain Shams Univ, 2009.

[5] W .M .S . Ahmed, Some factors affecting runner formation and transplants production in strawberry nursery. M.Sc. Thesis, Fac. Agric., Ain Shams Univ., vol. 52 , pp. 2011.

[6] T. G. A. Ali, Physiological studies on growth, seeds yield and its quality of common bean. Ph. D Thesis. Fac. of Agric., Benha univ, 2010.

[7] Y. Bashan, LE. de-Bashan, Bacteria / plant growth-promotion. In: Hillel D (ed) Encyclopedia of soils in the environ, vol. 1, Elsevier, Oxford, Uk, pp. 103-115, 2005.

[8] J. Brown, O. Lilliland, Rapid determination of potassium and sodium in plant material and soil extracts by flame photometric. Proc. Amer. Soc. Hort. Sci, vol. 48, pp. 341- 346, 1946.

[9] J. Cervantes-Martinez, S. Lopez-Diaz, B. Rodriguez-Garay, Detection of the effects of Methylobacterium in Agave tequilana Weber var. azul by laser-induced fluorescence. Plant Sci., vol. 166 , pp. 889-892, 2004.

[10] T. H. David, J. F. Dill, Vegetative and floral characteristics of six strawberry cultivars 
associated with fruit size, yield and susceptibility to tarnished plant bug injury. Acta. Hort., vol. 626, pp. 161-167, 2003.

[11] D.A. Dhale, S.N. Chatte, V.T. Jadhav, Effect of Bioinoculents on Growth, Yield and Fibre Quality of Cotton under Irrgation. Univ, Parbhani M.S., Res J Agric Biolo Sci, vol. 6(4), pp. 542-547, 2010.

[12] N.V. Doronina, Y.A. Trotsenko, Methylophilus leisingerii: A novel species of restricted facultatively methylotrophic bacteria. Mikrobiologiya, vol. 63(3), pp. 529-536, 1994.

[13] M. S. A. El-Badawy, Effect of spray with some safety compounds on growth and productivity of some strawberry cultivars. M.Sc. Thesis. Fac. Of Agric., Benha univ. Egypt. 60pp, 2014.

[14] W. A. El-Tohamy, H. M. El-Abagy, N. H. M. El-Greadly, Studies on the effect of putrescin, yeast and vitamin $\mathrm{C}$ on growth, yield and physiological responses of eggplant (Solanum melongena L.) under sandy soil conditions. Aust. J.Basic \& Appl. Sci., vol. 2 (2), pp. 296300, 2008.

[15] R. A. Fletcher, D. McCullagh, Cytokininin duced chlorophyll formation in cucumber cotyledons. Planta, vol. 101, pp. 88-90, 1971.

[16] E. Glickmann, S. Dessaux, A critical examination of the specifity of the Salkowski reagent for indolic compounds produced by the phytopathogenic bacteria. Appl. Environ. Microbiol., vol. 61, pp. 793-796, 1995.

[17] K. A. Gomez, A. A. Gomez, Statistical procedures for agriculture research. International Rice Research institute. Textbook vol. (2 ED.), pp. 84 -297, 1984.

[18] C. S. James, Analytical chemistry of foods Blokie Academic, proffessional, London, 1995.

[19] F. C. Koch, T. L. McMeckin, Anew direct nasalization micro keldahl method and ammonium. J. Amer. Soc. Chem., vol. 46, pp . $521,1924$.

[20] M. Madhaiyan, S. Poonguzhali, JH. Ryu, S. ATM, Regulation of ethylene levels in canola (Brassica campestris) by 1-aminocyclopropane1-carboxylate deaminase-containing
Methylobacterium fujisawaense. Planta vol. 224, pp. 268-278, 2006.

[21] R. H. Molinar, M. yang, Strawberry variety research- Fresno- country. (c.a. Computer Research CAB abstracts 2007-2008), 2006.

[22] S. M. R. Mosalem, Physiological studies on growth, yield and quality of some strawberry cultivar. M.Sc. Thesis. Fac. Of Agric., Benha univ. .90pp, 2010.

[23] N. Nelson, A photometric adaptation of the somogyi methods for determination of glucose. J. Biology. Chem. vol. 195, pp. 19-23, 1974.

[24] ZS. Omer, R. Tombolini, A. Broberg, B. Gerhardson, Indole-3-acetic acid production by pink-pigmented facul-tative methylotrophic bacteria. Plant growth Regul, vol. 43, pp. 93-96, 2004.

[25] E. Pregl, Quantitative organic micro analysis. $4^{\text {th }}$ Ed. J. Chundril, London, 1945.

[26] D. K. Qurecky, M. C. Bourne, Measurement of strawberry texture. J. Amer. Sci., vol. 93, pp. 317-339, 1968

[27] P. Raja, S. P. Sundaram, Combined inoculation effect of pink pigmented facultative Methylobacterium (PPFM) and other bioinoculants on cotton. Asian J. Bio. Sci., vol. 1 (2), pp. 39-44, 2006.

[28] S. S. A. K. Ramandeep, S. S. S. Navprem, Evaluation of strawberry (Fragaria $x$ ananassa Duch.) cultivars for fruit quality and biochemical characters under North-Western plains of India. HortFlora Res. Spectrum, vol. 5(4), pp. 295-300, 2016.

[29] E. H. A . Saleh, Studies on strawberry nutriton in sandy soil under drip irrigation system M.Sc. Thesis, Fac. Of Agric. Moshtohor, Benha Uniiv., Egypt, 2004.

[30] M. Somogyi, Noted on sugar determination. J. Biol. Chem. vol. 195, pp. 19-23, 1952.

[31] E. Trough, Meyer. Improvement in denies calorimetric method for phosphorus and arsenic. Indian English Chemistry Analysis Edition. vol. 1, pp. 136- 139, 1939.

[32] U .L . Yadava, Aprpid and non- destructure method to determine chlorophyll in intact leaves. Hort. Sci, vol. 21 , pp. 1449-1450, 1986. 